\title{
Iron Deficiency Anemia and Serum Hepcidin Level in Children with Typhoid Fever: A Case-Control Study
}

\author{
Ghada Mohamed $^{1}$ Samir Aboelhassan ${ }^{1}$ Maysaa El Sayed Zaki ${ }^{2}$ Yahya Wahba1(i) \\ ${ }^{1}$ Department of Pediatrics, Faculty of Medicine, Mansoura University, \\ Mansoura, Egypt \\ 2 Department of Clinical Pathology, Faculty of Medicine, Mansoura \\ University, Mansoura, Egypt \\ Address for correspondence Yahya Wahba, MD, Department of \\ Pediatrics, Faculty of Medicine, Mansoura University, \\ Mansoura 35516, Egypt (e-mail: wahbayahya2007@mans.edu.eg). \\ J Pediatr Infect Dis 2020;15:288-292.
}

\begin{abstract}
Objective Typhoid fever is a common systemic bacterial infection in children with a complex interplay between serum hepcidin and iron. We investigated the relationship between iron deficiency anemia (IDA) and serum hepcidin level in children with acute typhoid fever.

Methods We conducted a preliminary case-control study in Mansoura University Children's Hospital, Egypt from April 2017 to May 2019 including 30 children aged 5 to 15 years with confirmed acute typhoid fever. We recruited 15 healthy nonanemic children, of comparable ages and sex as controls from the same hospital while attending for nonfebrile complaints. Typhoid fever cases were subdivided according to IDA existence into 16 cases with IDA and 14 non-IDA cases. We excluded all children having diseases which may affect serum iron and hepcidin levels, for example, liver, blood, gastrointestinal, and kidney diseases, and patients receiving drugs interfering with iron metabolism. All participants were subjected to complete blood count, serum ferritin, iron, hepcidin levels, and total iron-binding capacity (TIBC).

Results In non-IDA typhoid fever group, serum iron level was significantly low, while serum hepcidin level was significantly high when compared with controls $(p<0.001$ and $p=0.02$, respectively). In IDA typhoid fever group, no statistically significant difference existed as regards serum hepcidin level when compared with controls

Keywords

- hepcidin

- iron deficiency anemia

- typhoid fever $(p=0.53)$. No significant correlations were detected between serum hepcidin levels and hemoglobin, serum iron, ferritin, and TIBC values in each group.

Conclusion Preexisting iron status could affect serum hepcidin level in patients with acute typhoid fever. Coexistence of IDA might oppose the up-regulatory effect of acute typhoid fever on serum hepcidin level.
\end{abstract}

\section{Introduction}

Typhoid fever is a common systemic infection caused by the gram-negative bacterium Salmonella enteric serovar typhi. It represents a global health problem with a higher impact on children in resource-limited areas of developing countries. ${ }^{1,2}$ Following ingestion of the organisms, they spread through the

received

March 21, 2020

accepted after revision

July 20, 2020

published online

September 4, 2020 reticuloendothelial system and remain in an incubation period for 1 to 2 weeks. Then bacteremia occurs with subsequent clinical manifestations in the form of fever and nonspecific symptoms as headache, abdominal pain, and nausea. ${ }^{3}$ Understanding the detailed pathogenesis of typhoid fever remains a challenge as it is caused by a human-restricted pathogen with a lack of convincing small-animal infection models. ${ }^{4}$ The factors 
regulating the availability of the critical micronutrient, iron between the host and invading pathogens still need further studies. ${ }^{5,6}$

Hepcidin is an antimicrobial low-molecular-weight peptide synthesized mainly by hepatocytes. ${ }^{7}$ It is feedback regulated by inflammation and iron status. ${ }^{8}$ Infections induce hepcidin synthesis through interleukin- $6^{9}$ that activates hepcidin gene transcription through the Janus kinase/signal transducer and activation of transcription 3 pathway. ${ }^{10-12}$ In extracellular infections, hepcidin aids in the host defense mechanisms by lowering serum iron levels. This deprives the organisms from their iron needs for growth and vital functions, and enhances oxidative stress. ${ }^{13}$ This occurs through down-regulation of ferroportin, the iron exporter on macrophages, duodenal enterocytes and hepatocytes, through binding to ferroportin receptors and inducing their internalization. ${ }^{14}$ With regard to intracellular bacterial infections such as typhoid fever, the relationship between the infection and serum hepcidin levels is not completely clear. It might be expected that severe infection could be caused by higher intracellular iron availability for the intramacrophage organism; however, some studies did not support this theory. ${ }^{15,16}$ The possible explanations for this could be compartmentalization of iron within macrophages limiting its availability to intracellular microbes ${ }^{17}$ or nitric oxide induced up-regulation of ferroportin and iron export. ${ }^{18}$

Moreover, it is proved that hepcidin is a key regulator of iron homeostasis in the pathogenesis of anemia. ${ }^{19,20}$ Its production is positively correlated with serum iron levels, when serum iron is abundant, hepcidin synthesis increases to limit further iron gut absorption and iron release from stores. When serum iron is low, less or no hepcidin is produced by hepatocytes allowing more iron to enter plasma. ${ }^{21}$

Despite several studies focused on the effects of typhoid fever on serum levels of hepcidin and iron, ${ }^{22-24}$ the effect of coexistence of iron deficiency anemia (IDA) together with acute typhoid fever on serum hepcidin level is unclear. In the current study, we investigated the relationship between IDA and serum hepcidin level in children with acute typhoid fever.

\section{Materials and Methods}

We conducted a preliminary case-control study in Mansoura University Children's Hospital, Egypt from April 2017 to May 2019 including 30 children aged 5 to 15 years with confirmed acute typhoid fever. Fifteen healthy nonanemic children, of comparable ages and sex were included as controls. They were recruited from the same hospital while attending for regular follow-up visits or minor nonfebrile complaints, for example, mild respiratory tract infections and mild gastroenteritis. Typhoid fever cases were further subdivided according to IDA existence into 16 cases with IDA and 14 non-IDA cases. Diagnosis of IDA was based on the following parameters: hemoglobin $(\mathrm{Hb})<11.5 \mathrm{~g} / \mathrm{dL}$, hematocrit (Hct) $<34 \%$, mean corpuscular volume (MCV) $<75 \mu \mathrm{m}^{3} /$ cell, and elevated red blood cells distribution width according to World Health Organization limits for 5 to 15 years old children. $^{25}$
The pediatric consultant clinically suspected acute typhoid fever if a patient had acute fever (axillary temperature $\geq 38^{\circ} \mathrm{C}$ ) for at least 3 days with nonspecific typhoid symptoms such as headache, malaise, abdominal pain, myalgia, nausea, anorexia, or constipation then referred for Widal's test. $^{26,27}$ Those with a positive Widal's test were subjected to blood cultures to confirm the diagnosis. ${ }^{27}$

Salmonella typhi diagnosis was made in the Department of Clinical Pathology of Faculty of Medicine, Mansoura University. We excluded all children having diseases which may affect serum iron and hepcidin levels, for example, liver, blood, gastrointestinal, and kidney diseases, and patients receiving drugs interfering with iron metabolism. Written informed consent was taken from caregivers of study participants. The study was accepted by Institutional Research Board of Faculty of Medicine, Mansoura University, Egypt (Code No: MS/17.02.38) and followed the Declaration of Helsinki of 1964, as revised in 2013.

Five milliliters of venous blood was withdrawn from each participant under a complete aseptic technique by a well-trained nurse using plastic disposable syringes. We used sera samples to carry out a semiquantitative Widal's agglutination test using the standard tube dilution procedure and Salmonella antigen kits (Gamma Biologicals, United States). The titer was determined as the highest dilution that showed visible agglutination. We considered positive titers if results were $\geq 1: 80$ for $O$ antigen, and $\geq 1: 160$ for $\mathrm{H}$ antigen. We used a negative saline control for each batch of Widal's tests. $^{28}$

With regard to blood cultures, 2 to $4 \mathrm{~mL}$ blood was directly inoculated in BacT/Alert culture bottles, and then incubated in the Bact/Alert automated system (Biomérieux, United States) for 5 days. Later on, subculture was done on MacConkey and Salmonella-Shigella agar and incubated for 18 to 24 hours at $37^{\circ} \mathrm{C}$. For negative cases, we repeated subcultures for 1 week. ${ }^{29}$ Identification of S. typhi was done by automated MicroScan WalkAway 96 plus System (Beckman Coulter, United States) for biochemical identification.

All participants were subjected to complete blood count, serum ferritin, iron, hepcidin levels, and total iron-binding capacity (TIBC). We analyzed complete blood count using the UniCel DxH 800 Coulter Cellular Analysis System (Beckman Coulter). Serum iron and unsaturated iron-binding capacity (UIBC) were measured by AU5810 Chemistry Analyzers (Beckman Coulter). TIBC was calculated by adding the value of serum iron to that of UIBC. Serum ferritin was estimated using sandwich enzyme-linked immunosorbent assay (ELISA) kits (DRG International, United States). ${ }^{30}$

Serum hepcidin level was assessed by ELISA using microtiter plate wells (USCN Life Science, United States) precoated with the specific antibody. We added samples or standards to the appropriate plate wells with a biotin-conjugated antibody preparation specific for hepcidin. Then, we added avidin conjugated to horseradish peroxidase to each plate well and incubated. Then, we added trimethyle benzidine (TMB) substrate solution, wells that contained hepcidin, biotin-conjugated antibody, and enzyme conjugated avidin exhibited a color change. The reaction was stopped by adding sulfuric acid solution. 
Table 1 Baseline characteristics of study groups

\begin{tabular}{|c|c|c|c|c|c|}
\hline & $\begin{array}{l}\text { Controls } \\
(n=15)\end{array}$ & $\begin{array}{l}\text { IDA typhoid fever } \\
\text { cases }(n=16)\end{array}$ & $\begin{array}{l}\text { Non-IDA typhoid fever } \\
\text { cases }(n=14)\end{array}$ & $\begin{array}{l}\text { Test of } \\
\text { significance }\end{array}$ & Post hoc test \\
\hline Age $(y)^{a}$ & $7.13(2.23)$ & $8.19(2.51)$ & $7.86(2.21)$ & $\begin{array}{l}F=0.82 \\
p=0.45\end{array}$ & $\begin{array}{l}P 1=0.22, P 2=0.41 \\
P 3=0.70\end{array}$ \\
\hline \multicolumn{6}{|l|}{ Sex ${ }^{b}$} \\
\hline Male & $8(53.3 \%)$ & $10(62.5 \%)$ & $8(57.1 \%)$ & \multirow{2}{*}{$\begin{array}{l}x^{2}=0.27 \\
p=0.87\end{array}$} & \multirow{2}{*}{$\begin{array}{l}P 1=0.61, P 2=0.84 \\
P 3=0.77\end{array}$} \\
\hline Female & 7 (46.7\%) & $6(37.5 \%)$ & 6 (42.9\%) & & \\
\hline
\end{tabular}

Abbreviations: $F$, one-way analysis of variance test; IDA, iron deficiency anemia; $P 1$, difference between controls and IDA typhoid fever cases; $P 2$, difference between controls and non-IDA typhoid fever cases; $P 3$, difference between IDA and non-IDA typhoid fever cases; $X^{2}$, chi-square test.

${ }^{\mathrm{a}}$ Data are shown as mean (standard deviation).

${ }^{\mathrm{b}}$ Number (percentage).

We measured the color changes spectrophotometrically at a wavelength of $450 \pm 10 \mathrm{~nm}$. The serum hepcidin concentration was then determined by comparing the optical density of the samples to the standard curve. ${ }^{31}$

We used SPSS version 25 (IBM Corp.; Armonk, New York, United States) and tested continuous data for normality using Shapiro-Wilk's test. Nonparametric data were presented as median (interquartile range), while parametric data were expressed as mean (standard deviation). We used one-way analysis of variance test to compare more than two independent groups (parametric) with post hoc Tukey's test to detect pairwise comparison. We used the Kruskal-Wallis' test for more than two independent groups (nonparametric) comparisons with Mann-Whitney's $U$ test to detect pairwise comparison. Categorical data were expressed as numbers and percentage, and analyzed using chi-square test. A $p \leq 0.05$ was considered significant. We determined the strength and direction of linear relationships between serum hepcidin levels and $\mathrm{Hb}$, serum iron, ferritin, and TIBC values in each group using Spearman's rank correlation.

\section{Results}

IDA and non-IDA typhoid fever groups were matched with controls as regards the age and sex $(p>0.05$, - Table 1$)$. In non-IDA typhoid fever group, serum iron level was significantly low, while serum hepcidin level was significantly high when compared with controls $(p<0.001$ and $p=0.02$, respectively, -Table 2). No significant differences existed

Table 2 Comparison of laboratory markers of the study groups

\begin{tabular}{|c|c|c|c|c|c|}
\hline $\begin{array}{l}\text { Laboratory } \\
\text { markers }\end{array}$ & $\begin{array}{l}\text { Controls } \\
(n=15)\end{array}$ & $\begin{array}{l}\text { IDA typhoid fever } \\
\text { cases }(n=16)\end{array}$ & $\begin{array}{l}\text { Non-IDA typhoid fever } \\
\text { cases }(n=14)\end{array}$ & $p$-Value & Post hoc test \\
\hline $\mathrm{Hb}(\mathrm{g} / \mathrm{dL})$ & $12.18(0.64)$ & $9.87(0.67)$ & $12.43(0.95)$ & $\begin{array}{l}\mathrm{F}=52.78 \\
p<0.001\end{array}$ & $\begin{array}{l}P 1<0.001, P 2=0.39 \\
P 3<0.001\end{array}$ \\
\hline RBCs $\left(\times 10^{6} / \mu \mathrm{L}\right)$ & $4.49(0.29)$ & $4.38(0.51)$ & $4.76(0.28)$ & $\begin{array}{l}\mathrm{F}=3.78 \\
p=0.03\end{array}$ & $\begin{array}{l}P 1=0.4, P 2=0.07 \\
P 3=0.01\end{array}$ \\
\hline Hct (\%) & $36.74(2.31)$ & $32.76(3.78)$ & $37.97(2.34)$ & $\begin{array}{l}\mathrm{F}=13.22 \\
p<0.001\end{array}$ & $\begin{array}{l}P 1<0.001, P 2=0.27 \\
P 3<0.001\end{array}$ \\
\hline $\mathrm{MCV}\left(\mu \mathrm{m}^{3} /\right.$ cell $)$ & $82.86(5.35)$ & $74.64(2.84)$ & $81.48(2.44)$ & $\begin{array}{l}\mathrm{F}=21.04 \\
p<0.001\end{array}$ & $\begin{array}{l}P 1<0.001, P 2=0.33 \\
P 3<0.001\end{array}$ \\
\hline MCH (pg/cell) & $26.62(1.81)$ & $22.57(1.92)$ & 26.51 (1.39) & $\begin{array}{l}F=27.33 \\
p<0.001\end{array}$ & $\begin{array}{l}P 1<0.001, P 2=0.87 \\
P 3<0.001\end{array}$ \\
\hline Ferritin $(\mathrm{ng} / \mathrm{mL})^{\mathrm{a}}$ & $\begin{array}{l}18.7 \\
(14.75-29.45)\end{array}$ & $24(14.9-38.5)$ & $21.5(9.675-63)$ & $\begin{array}{l}\text { KW } \\
p=0.91\end{array}$ & $\begin{array}{l}P 1=0.66, P 2=0.77 \\
P 3=0.93\end{array}$ \\
\hline TIBC $(\mu \mathrm{g} / \mathrm{dL})$ & $495.08(167.41)$ & $361.12(209.2)$ & $394.8(188.25)$ & $\begin{array}{l}\mathrm{F}=1.75 \\
p=0.19\end{array}$ & $\begin{array}{l}P 1=0.08, P 2=0.21 \\
P 3=0.65\end{array}$ \\
\hline Iron $(\mu \mathrm{g} / \mathrm{dL})$ & $52.59(14)$ & $11.81(6.45)$ & $27.67(6.18)$ & $\begin{array}{l}\mathrm{F}=70.48 \\
p<0.001\end{array}$ & $\begin{array}{l}P 1<0.001, P 2<0.001 \\
P 3<0.001\end{array}$ \\
\hline $\begin{array}{l}\text { Hepcidin } \\
(\mathrm{ng} / \mathrm{mL})^{\mathrm{a}}\end{array}$ & $\begin{array}{l}96.55 \\
(59.675-288.5)\end{array}$ & $\begin{array}{l}51.3 \\
(30.9-297.45)\end{array}$ & $\begin{array}{l}607.7 \\
(84.45-969.775)\end{array}$ & $\begin{array}{l}\mathrm{KW} \\
p=0.015\end{array}$ & $\begin{array}{l}P 1=0.53, P 2=0.02 \\
P 3=0.009\end{array}$ \\
\hline
\end{tabular}

Abbreviations: F, one-way analysis of variance test; Hb, hemoglobin; Hct, hematocrit; IDA, iron deficiency anemia; KW, Kruskal-Wallis' test; MCH, mean corpuscular hemoglobin; $M C V$, mean corpuscular volume; $P 1$, difference between controls and IDA typhoid fever cases; $P 2$, difference between controls and non-IDA typhoid fever cases; P3, difference between IDA and non-IDA typhoid fever cases; RBCs, red blood cells; TIBC, total iron-binding capacity.

Note: Data are shown as mean (standard deviation).

àdian (interquartile range). 
Table 3 Correlation between serum hepcidin levels and iron deficiency anemia indices among study groups

\begin{tabular}{|c|c|c|c|c|c|c|}
\hline \multirow[t]{3}{*}{ IDA indices } & \multicolumn{6}{|c|}{ Serum hepcidin levels } \\
\hline & \multicolumn{2}{|c|}{ Controls } & \multicolumn{2}{|c|}{ IDA typhoid fever cases } & \multicolumn{2}{|c|}{$\begin{array}{l}\text { Non-IDA typhoid fever } \\
\text { cases }\end{array}$} \\
\hline & $r$ & $P$ & $r$ & $P$ & $r$ & $P$ \\
\hline $\mathrm{Hb}$ & -0.486 & 0.078 & 0.309 & 0.244 & 0.323 & 0.259 \\
\hline Serum iron & 0.213 & 0.464 & -0.003 & 0.991 & -0.288 & 0.318 \\
\hline TIBC & 0.203 & 0.527 & 0.099 & 0.716 & 0.252 & 0.43 \\
\hline Ferritin & -0.130 & 0.659 & 0.046 & 0.869 & 0.415 & 0.14 \\
\hline
\end{tabular}

Abbreviations: $\mathrm{Hb}$, hemoglobin; IDA, iron deficiency anemia; $P$, probability value; $r$, Spearman's rank correlation coefficient; TIBC, total iron-binding capacity.

between non-IDA typhoid fever group and controls as regards $\mathrm{Hb}$, Hct, MCV, mean corpuscular hemoglobin $(\mathrm{MCH}), \mathrm{TIBC}$, and serum ferritin $(p>0.05$, - Table 2$)$.

In IDA typhoid fever group, no statistically significant difference existed as regards serum hepcidin level when compared with controls $(p=0.53)$. Serum iron level and $\mathrm{Hb}$, $\mathrm{Hct}, \mathrm{MCV}$, and $\mathrm{MCH}$ were significantly lower in IDA typhoid fever group than controls $(p<0.001)$, while serum ferritin and TIBC showed insignificant differences $(p=0.66$ and 0.08 , respectively, $\boldsymbol{二}$ Table 2 ). No statistically significant correlations were detected between serum hepcidin levels and $\mathrm{Hb}$, serum iron, ferritin, and TIBC in each group ( $p>0.05$ for each variable, -Table 3).

\section{Discussion}

In the present study, serum iron in non-IDA typhoid fever group showed a lower level than controls attributed to the higher hepcidin level. Our result was in agreement with Darton et al who investigated alterations in iron/inflammatory indices and hepcidin following the experimental human typhoid challenge and reported rapid elevation of hepcidin levels during acute typhoid infection causing hypoferremia. ${ }^{23}$ The elevation of serum hepcidin level in the nonanemic typhoid fever group could be attributed to $S$. typhi infection, possibly mediated by inflammatory cytokines as interleukin-6, interleukin-1 $\beta$, and interleukin-22. ${ }^{12,32}$

In the current work, serum hepcidin levels were lower in typhoid fever cases with IDA than controls but without statistical significance. This finding suggests that preexisting IDA counteracts infection-induced hepcidin up-regulation. However, lack of significant correlations between serum hepcidin and iron levels in both typhoid fever groups suggests that other variables may interact including pathogen factors such as severity of infection and virulence of invading pathogens. This speculation necessitates further large-scale studies including more host and pathogen variables to detect the exact factors affecting serum hepcidin level among typhoid fever patients.

With regard to ferritin and TIBC, their levels were affected significantly by the acute infectious process explaining the insignificant differences between studied IDA cases and controls. $^{33}$

The limitations of our study are a single-center study with a small sample size and limited studied variables.
We performed post hoc power analysis using $G^{*}$ Power program ${ }^{34}$ for the three groups taking in consideration the correlation between $\mathrm{Hb}$ and hepcidin in each group as the outcome of interest. Study powers were 47, 21.7, and 20.5 in control, IDA typhoid, and non-IDA typhoid groups, respectively.

\section{Conclusion}

Preexisting iron status could affect serum hepcidin level in children with acute typhoid fever. Coexistence of IDA might oppose the up-regulatory effect of acute typhoid fever on serum hepcidin level. Larger adequately powered studies would be needed to validate our findings and to verify other possible variables.

Funding

None.

Conflict of Interest

None declared.

\section{References}

1 Buckle GC, Walker CLF, Black RE. Typhoid fever and paratyphoid fever: Systematic review to estimate global morbidity and mortality for 2010. J Glob Health 2012;2(01):010401

2 Crump JA, Luby SP, Mintz ED. The global burden of typhoid fever. Bull World Health Organ 2004;82(05):346-353

3 Parry CM, Hien TT, Dougan G, White NJ, Farrar JJ. Typhoid fever. N Engl J Med 2002;347(22):1770-1782

4 Strugnell RA, Scott TA, Wang N, et al. Salmonella vaccines: lessons from the mouse model or bad teaching? Curr Opin Microbiol 2014; 17:99-105

5 Ganz T. Iron in innate immunity: starve the invaders. Curr Opin Immunol 2009;21(01):63-67

6 Hood MI, Skaar EP. Nutritional immunity: transition metals at the pathogen-host interface. Nat Rev Microbiol 2012;10(08): 525-537

7 Park $\mathrm{CH}$, Valore EV, Waring AJ, Ganz T. Hepcidin, a urinary antimicrobial peptide synthesized in the liver. J Biol Chem 2001;276(11):7806-7810

8 Liu J, Sun B, Yin H, Liu S. Hepcidin: a promising therapeutic target for iron disorders: a systematic review. Medicine (Baltimore) 2016;95(14):e3150

9 Nemeth E, Rivera S, Gabayan V, et al. IL-6 mediates hypoferremia of inflammation by inducing the synthesis of the iron regulatory hormone hepcidin. J Clin Invest 2004;113(09):1271-1276 
10 Pietrangelo A, Dierssen U, Valli L, et al. STAT3 is required for IL-6gp130-dependent activation of hepcidin in vivo. Gastroenterology 2007;132(01):294-300

11 Verga Falzacappa MV, Vujic Spasic M, Kessler R, Stolte J, Hentze MW, Muckenthaler MU. STAT3 mediates hepatic hepcidin expression and its inflammatory stimulation. Blood 2007;109(01): 353-358

12 Wrighting DM, Andrews NC. Interleukin-6 induces hepcidin expression through STAT3. Blood 2006;108(09):3204-3209

13 Cassat JE, Skaar EP. Iron in infection and immunity. Cell Host Microbe 2013;13(05):509-519

14 Nemeth E, Tuttle MS, Powelson J, et al. Hepcidin regulates cellular iron efflux by binding to ferroportin and inducing its internalization. Science 2004;306(5704):2090-2093

15 Stefanova D, Raychev A, Arezes J, et al. Endogenous hepcidin and its agonist mediate resistance to selected infections by clearing non-transferrin-bound iron. Blood 2017;130(03):245-257

16 Willemetz A, Beatty S, Richer E, et al. Iron- and hepcidin-independent downregulation of the iron exporter ferroportin in macrophages during Salmonella infection. Front Immunol 2017; 8:498

17 Ganz T. Iron and infection. Int J Hematol 2018;107(01):7-15

18 Nairz M, Schleicher U, Schroll A, et al. Nitric oxide-mediated regulation of ferroportin-1 controls macrophage iron homeostasis and immune function in Salmonella infection. J Exp Med 2013; 210(05):855-873

19 Fleming RE, Sly WS. Hepcidin: a putative iron-regulatory hormone relevant to hereditary hemochromatosis and the anemia of chronic disease. Proc Natl Acad Sci U S A 2001;98(15):8160-8162

20 Weiss G, Goodnough LT. Anemia of chronic disease. N Engl J Med 2005;352(10):1011-1023

21 Ramos E, Kautz L, Rodriguez R, et al. Evidence for distinct pathways of hepcidin regulation by acute and chronic iron loading in mice. Hepatology 2011;53(04):1333-1341

22 Chlosta S, Fishman DS, Harrington L, et al. The iron efflux protein ferroportin regulates the intracellular growth of Salmonella enterica. Infect Immun 2006;74(05):3065-3067
23 Darton TC, Blohmke CJ, Giannoulatou E, et al. Rapidly escalating hepcidin and associated serum iron starvation are features of the acute response to typhoid infection in humans. PLoS Negl Trop Dis 2015;9(09):e0004029

24 Kim DK, Jeong JH, Lee JM, et al. Inverse agonist of estrogen-related receptor $\gamma$ controls Salmonella typhimurium infection by modulating host iron homeostasis. Nat Med 2014;20(04):419-424

25 Özdemir N. Iron deficiency anemia from diagnosis to treatment in children. Turk Pediatri Ars 2015;50(01):11-19

26 Habte L, Tadesse E, Ferede G, Amsalu A. Typhoid fever: clinical presentation and associated factors in febrile patients visiting Shashemene Referral Hospital, southern Ethiopia. BMC Res Notes 2018;11(01):605

27 Upadhyay R, Nadka MY, Muruganathan A, et al. API recommendations for the management of typhoid fever. J Assoc Physicians India 2015;63(11):77-96

28 Ohanu ME, Iroezindu MO, Maduakor U, Onodugo OD, Gugnani HC Typhoid fever among febrile Nigerian patients: prevalence, diagnostic performance of the Widal test and antibiotic multi-drug resistance. Malawi Med J 2019;31(03):184-192

29 Singh L, Cariappa MP. Blood culture isolates and antibiogram of Salmonella: experience of a tertiary care hospital. Med J Armed Forces India 2016;72(03):281-284

30 White D, Kramer D, Johnson G, Dick F, Hamilton H. Estimation of serum ferritin by using enzyme immunoassay method. Am J Clin Pathol 1986;72:346-351

31 Manolov V, Atanasova B, Vasilev V, Tzatchev K, Velizarova M. ELISA method for serum hepcidin quantification in Bulgarian population. Acta Medica Bulgarica 2014;41(01):22-29

32 Smith CL, Arvedson TL, Cooke KS, et al. IL-22 regulates iron availability in vivo through the induction of hepcidin. J Immunol 2013;191(04):1845-1855

33 Jain S, Gautam V, Naseem S. Acute-phase proteins: as diagnostic tool. J Pharm Bioallied Sci 2011;3(01):118-127

34 Faul F, Erdfelder E, Lang AG, Buchner A. G*Power 3: a flexible statistical power analysis program for the social, behavioral, and biomedical sciences. Behav Res Methods 2007;39(02):175-191 